Charlotte A. Palmer and Thomas E. Martin Operation Wallacea, Old Bolingbroke, Lincolnshire, UK.

E-mail charlotte.palmer@opwall.com

STEPHEN DURAND Division of Forestry Wildlife and National Parks, Ministry of Agriculture and Fisheries, Roseau, Commonwealth of Dominica

Myles Lamont TerraFauna Wildlife Consulting Inc., Surrey, British Columbia, Canada

\section{Successful prosecution of slow loris traders in Indonesia}

On 15 February 2018 a wildlife trader in Lubuk Basung, West Sumatra, Indonesia, was sentenced to 3.5 years in prison, with a fine of IDR 100 million (c. USD 7,250) and a 6-month subsidiary sentence, after his arrest last year for trading slow lorises (Nycticebus spp.). A trafficker was sentenced to 3 years in prison with the same fine and subsidiary sentence. The perpetrators were tracked by posts on their Facebook pages that advertised the animals for sale.

Indonesia is home to seven species of slow loris, and all of them are categorized as threatened (with two Critically Endangered) on the IUCN Red List, and all are included on Appendix 1 of CITES. Slow lorises were included on Indonesia's list of protected species in 1973, and buying, selling or keeping them as pets is illegal. According to Indonesia's Law No. 5 (1990) on the Conservation of Biological Resources and Ecosystems, perpetrators can receive a maximum of 5 years in prison and a maximum fine of IDR 100 million. Despite the extreme threat of illegal trade to the survival of slow lorises in Indonesia, open trade in markets or on social media still flourishes.

The convicted trader offered slow lorises and other wildlife, including the protected changeable hawk-eagle Nisaetus cirrhatus, for sale on his Facebook page. The asking price for a Sumatran slow loris Nycticebus hilleri offered for sale on 30 August 2017 was USD 36. On 23 September 2017 the local authorities arrested the wildlife trader whilst he was in possession of six Sumatran slow lorises and two albino common palm civets Paradoxurus hermaphroditus, the latter for sale at USD 109 each, and on the same day a wildlife trafficker with three Sumatran slow lorises was arrested. The nine slow lorises comprised two babies, two juveniles and five adults (seven females, two males). They must have been obtained recently from the wild as they were still healthy and none had their teeth cut (slow lorises are the only venomous primate and traders often cut their teeth to make them more suitable as pets).

Two weeks later, eight of the nine Sumatran slow lorises were released in the Bung Hatta Forest Park, east of the city of Padang. Two slow loris species occur on the island of
Sumatra, yet their distribution has not been documented, nor has any study been made of their behavioural ecology. These are crucial prerequisites for release. No data are available regarding whether assessment of the quality and suitability of the habitat were made prior to release. Reintroductions of non-endemic species, as well as introducing animals into areas with no suitable habitat, are additional threats to slow lorises throughout Asia.

Prosecuting and sentencing law breakers punishes the offenders and acts as a deterrent for future law breakers. This case is one of few in which a wildlife trader and wildlife trafficker have been successfully prosecuted and sentenced for trading and trafficking slow lorises in Indonesia. We hope that these convictions represent a changing trend in wildlife enforcement in the country.

K.A.I. NEKARIS and V. NIJMAN Nocturnal Primate Research Group and Oxford Wildlife Trade Research Group, Oxford Brookes University, UK. E-mail anekaris@brookes.ac.uk

\section{Sightings of reintroduced northern bald ibis Geronticus eremita crossing between Spain and Morocco are probably hand-reared rather than wild-born}

The report of six northern bald ibis Geronticus eremita arriving in Morocco from Spain in November 2016 (Muñoz \& Ramirez, Oryx, 51, 204-205) was claimed to be the first confirmed sighting of the reintroduced Spanish population crossing from Europe to Africa. Significantly, there have been several additional sightings of birds leaving from Spain and crossing to Africa before and since this date (Migres Foundation, 2016 \& 2017, Unpublished Reports). We present these data and cross-reference them to timings and information from the reintroduction project Proyecto Eremita (López \& Quevedo, 2016, pp. 5457, in Boehm \& Bowden, eds, Northern Bald Ibis Conservation \& Reintroduction Workshop) in Andalusia, Spain.

Post-breeding observations of soaring birds since 1999, by the Migres Foundation observation teams at Tarifa, Cazalla and Algarrobo in southern Spain during July-December, have recorded northern bald ibises on at least 15 occasions (Table 1). These have mainly been birds leaving Spain towards Morocco. The highest numbers were observed in 2016, and these include the six birds confirmed to arrive in Tangiers by Muñoz \& Ramirez. Table 1 shows crossings both before and after, as well as a group in July 2016 that appears to have made the crossing and then returned, minus one individual, to Spain the following day.

The observation of 11 birds that crossed on 23 September 2016 is of interest because 11 hand-reared juveniles, released as part of a larger group of 25 in July, disappeared from 